\title{
PERDA MANOKWARI KOTA INJIL: MAKNA DAN KONSEKUENSI BAGI GEREJA- GEREJA DI INDONESIA
}

\author{
Binsar A. Hutabarat \\ Peneliti Senior Reformed Center for Religion and Society
}

ABSTRACT: This article entitled "Provincial Regulation of Gospel City Manokwari: Significance and Consequences for the Churches in Indonesia" will first explore the presence of Provincial Regulation (Perda or peraturan daerah) of Gospel City Manokwari. The article is based on data collected by the author in a field research in areas related to the initiation of these regulations, and particularly in Manokwari. The author will then analyze this regulation from the standpoint of Christian theology, and further explain the implications of these regulations for the churches in Indonesia. The findings from this study is that Provincial Regulation of Gospel City Manokwari, which is initiated in Manokwari, Papua, is not part of Indonesian Christians strategy in general, and even become a detriment of the testimony of churches in Indonesia.

KEYWORDS: Provincial Regulation (Perda or Peraturan Daerah) on religion, Perda on Gospel, the Gospel City Manokwari, state and religion, Christian theology

ABSTRAK: Artikel yang berjudul "Perda Manokwari Kota Injil: Makna dan Konsekuensi bagi Gereja-gereja di Indonesia" ini 
pertama-tama akan memaparkan mengenai kehadiran Perda (Peraturan Daerah) Manokwari Kota Injil. Pemaparan tersebut didasarkan pada data-data yang dikumpulkan penulis dalam penelitian lapangan di Manokwari khususnya dan juga daerah lain yang terkait dengan dicetuskannya Perda tersebut. Kemudian penulis akan menganalisis Perda tersebut dari sudut pandang teologi Kristen, dan selanjutnya menjelaskan mengenai konsekuensi kehadiran Perda tersebut bagi gerejagereja di Indonesia. Temuan dari kajian ini adalah bahwa Perda Manokwari Kota Injil yang dicetuskan di Manokwari, Papua, tersebut bukan bagian dari strategi umat Kristen Indonesia pada umumnya, dan justru merugikan kesaksian gereja-gereja di Indonesia.

KATA KUNCI: perda (Peraturan Daerah) agama, Perda Injil, Manokwari Kota Injil, negara dan agama, teologi Kristen

\section{PENDAHULUAN}

Kehadiran berbagai Perda (Peraturan Daerah) bernuansa agama di Indonesia pada umumnya memang tidak secara terang-terangan menamakan dirinya sebagai Perda agama. Namun, melihat isinya yang memuat nilai-nilai agama tertentu jelas menunjukkan bahwa itu adalah sebuah Perda agama. ${ }^{1}$

${ }^{1}$ Perda berbasis syariat itu setidaknya dapat diklasifikasikan ke dalam tiga hal, yaitu: (i) ketertiban masyarakat seperti pelarangan aktivitas pelacuran dan pembatasan distribusi konsumsi minuman beralkohol; (2) kewajiban dan ketrampilan keagamaan seperti pembayaran zakat dan 
Perda ini biasa disebut Perda yang melanggar hak-hak asasi manusia karena isinya terindikasi mendiskriminasikan agamaagama lain. Perda bernuansa agama sukses diberlakukan di beberapa provinsi di Indonesia. Berbekal dukungan mayoritas, Perda bernuansa agama itu setidaknya telah diberlakukan di tingkat provinsi (6), kabupaten (38), kota (12). ${ }^{2}$ Pengalaman sukses menghadirkan Perda agama itu ternyata telah mendorong agama-agama lain yang terdiskriminasikan untuk juga menghadirkan Perda agama pada daerah di mana agamaagama tertentu menjadi mayoritas, seperti misalnya terkait kehadiran Perda Kota Injil di Manokwari yang mayoritas penduduknya beragama Kristen.

Timbul pertanyaan, apakah kehadiran Perda Manokwari Kota Injil yang awalnya merupakan usulan tokoh-tokoh agama Kristen tentang "Raperda Pembinaan Mental dan Spiritual"3 yang kemudian direspon oleh pemerintah daerah Manokwari, dan dituangkan dalam Rancangan Peraturan Daerah (Raperda) itu bisa disebut sebagai bagian dari strategi gereja dalam merespon maraknya Perda-Perda syariah di berbagai daerah di Indonesia? Dan apakah konsekuensinya bagi gereja-gereja di

kemampuan baca Al Quran; dan (3) simbolisme keagamaan berupa pakaian busana Muslim. Arskal Salim, "Perda Berbasis Agama dan Perlindungan Konstitusional Penegakan HAM", Jurnal Perempuan, No. 60 (September 2008).

${ }^{2}$ Lihat "Proyek Syariahisasi Daerah", Reformed Review, Vol I, No. 1. (2007), 50-57.

${ }^{3}$ Lihat, Rancangan Peraturan Daerah Kabupaten Manokwari Sebagai Daerah Injil tahun 2007. Lihat juga, Naskah Akademik Rancangan Perda tentang Pembinaan Mental Spiritual tahun 2008. 
Indonesia.

\section{MANOKWARI SELAYANG PANDANG}

Papua adalah daerah terakhir yang masuk menjadi bagian wilayah Republik Indonesia. Tepatnya, tanggal 1 Mei 1963, Irian Barat-kini disebut Papua-resmi menjadi wilayah Republik Indonesia. ${ }^{4}$ Nama Irian Barat kemudian diganti menjadi Irian Jaya. Nama ini adalah usulan Frans Kaisepo, seorang yang pernah menjadi gubernur Papua. Nama Irian populer sebagai akronim "Ikut (pro) Republik Indonesia Anti Nederland". Nama Irian Jaya Barat ini ditetapkan oleh Undang Undang Nomor 45 Tahun 1999, kemudian berdasarkan Peraturan Pemerintah Nomor 24 Tahun 2007 tanggal 18 April 2007, pada masa Presiden Abdurrahman Wahid nama Irian Jaya diubah kembali menjadi Papua atas usulan masyarakat Papua. ${ }^{5}$

Rakyat Papua sesungguhnya tidak ingin daerahnya terbagi-bagi, karena umumnya mereka mengakui sebagai sebuah komunitas yang satu, yakni provinsi Papua. Itulah

${ }^{4}$ Provinsi Papua baru kembali ke pangkuan Ibu Pertiwi pada 1 Mei 1963, itu pun masih harus melewati Proses Penentuan Pendapat rakyat (Pepera) pada tahun 1969, meski Papua adalah bagian yang tak terpisahkan dari apa yang dikenal dengan Indonesia Raya, sebagaimana dikemukakan oleh Blaskett. Enam hari sesudah Proklamasi Kemerdekaan, tepatnya tanggal 23 Agustus 1945, Presiden Soekarno mengumandangkan kebijakan persatuan Indonesia, “Dari Sabang Sampai Merauke." Lihat, Jacobus Perviddya Solossa, Otonomi Khusus Papua: Mengangkat Martabat Rakyat Papua Di Dalam NKRI (Jakarta: Sinar Harapan, 2005), 4.

${ }^{5}$ Demmy Antoh, Rekonstruksi danTransformasi Nasionalisme (Jakarta: Pustaka Sinar Harapan, 2007). 30 
sebabnya kehadiran Provinsi Papua Barat awalnya menimbulkan kontroversi, namun, akhirnya berhasil dicapai kesepakatan. Karena pada umumnya orang Papua tidak ingin terpisah menjadi beberapa provinsi. Masyarakat Papua mengakui bahwa mereka adalah satu, dan mesti berada dalam satu provinsi, yaitu Provinsi Papua. Pemekaran daerah oleh sebagian orang Papua dianggap sebagai ancaman bagi orangorang asli Papua. ${ }^{6}$ Pemekaran daerah dicurigai menjadi alat untuk memecah belah Papua.

Manokwari adalah ibu kota Provinsi Papua Barat, sebuah provinsi baru setelah dimekarkan dari Provinsi Papua7 (Irian Jaya). Setelah pemekaran, Papua dibagi menjadi dua provinsi yakni Provinsi Papua dengan ibu kota Jayapura, dan Papua Barat dengan ibu kota Manokwari. Usulan pemekaran untuk Papua masih terus berlangsung, dan menimbulkan banyak kontroversi. Persoalan utamanya adalah usulan pemekaran bukan berasal dari masyarakat Papua, tetapi dari luar Papua.

Papua Barat merupakan daerah yang memiliki potensi luar biasa, baik kesuburan alamnya, kandungan barang-barang tambang, hasil hutan maupun keindahan alamnya sebagai

${ }^{6}$ Pemekaran Provinsi dan kabupaten di Tanah Papua Barat adalah ancaman bagi orang-orang asli Papua, tetapi sebaliknya keuntungan dan peluang besar bagi orang-orang Indonesia (orang luar Papua). Socratez Sofyan Oman, Pemusnahan Etnis Melanesia (Yogyakarta: Galang Press, 2007), 435.

${ }^{7}$ Nama Papua berasal dari kata dalam bahasa Melayu, yaitu "puapua" yang berarti "rambut keriting" dan kemudian disingkat Papua. Rainer Scheunemann, ed., Fajar Merekah di Tanah Papua (Papua: Panitia Jubelium Emas 150 Tahun Papua, 2005), 30. 
tempat pariwisata. Belum lagi hasil laut seperti mutiara dan rumput laut. Papua Barat juga telah memiliki industri tradisional tenun ikat kain timor yang dihasilkan di Sorong. Papua Barat sendiri terbagi atas 9 kabupaten dan kota, yaitu: Kabupaten Fak-Fak, Kaimana, Manokwari, Raja Ampat, Sorong, Sorong Selatan, Teluk Bintuni, Teluk Wondama, Kota Sorong. Sedang Manokwari sebagai ibu kota provinsi terbagi atas 12 kecamatan dan 132 desa. Kabupaten Manokwari biasa disebut sebagai kota buah-buahan, karena kesuburan tanahnya yang menghasilkan berbagai jenis tumbuh-tumbuhan. Manokwari juga memiliki suku-suku yang majemuk. Penduduk asli Manokwari terdiri dari beberapa suku, yaitu Sough, Karon, Hatam, Meyeh dan Wamesa, dan suku-suku itu memiliki budaya yang berbeda satu sama lain.

Manokwari diakui sebagai pintu gerbang masuknya Injil ke Tanah Papua. Tiap tahun di kota itu, khususnya Pulau Mansinam, yang berada dalam lingkup Kabupaten Manokwari, masyarakat dari berbagai penjuru Papua tumpah ruah ke tempat tersebut untuk merayakan masuknya Injil ke Tanah Papua. Itulah sebabnya julukan Kota Injil untuk Manokwari bukan sesuatu yang baru, karena telah melekat lama di benak orang Papua, walaupun formalisasi sebutan itu baru dikenakan ketika Dominggus Mandacan terpilih sebagai Bupati Manokwari.

\section{MAKNA PERDA MANOKWARI KOTA INJIL}

Pemicu yang paling kuat lahirnya usulan kontroversial tokoh-tokoh agama Kristen di Papua dalam bentuk Perda Injil 
adalah pembangunan Masjid Raya, sebuah masjid yang berada pada tempat yang strategis, dekat lapangan udara Manokwari, dan dianggap berpotensi menghapus tanda-tanda Manokwari sebagai Kota Injil.

Tokoh-tokoh agama Kristen di Papua umumnya sepakat bahwa kehadiran Masjid Raya di Manokwari telah melukai perasaan umat Kristen Papua, dan menimbulkan perasaan terdiskriminasikan. Penolakan terhadap Masjid Raya itu datang dari berbagai kalangan umat Kristen di Papua. Kekecewaan ini selalu saja dihembuskan tokoh-tokoh agama Kristen di Papua, bahkan ini juga diutarakan oleh pejabat-pejabat lembaga pemerintahan yang beragama Kristen di Papua, baik eksekutif, maupun legislatif. ${ }^{8}$

Pada akhir tahun 2005, umat Muslim Manokwari memutuskan untuk membangun Masjid Raya. Rencana pembangunan Masjid Raya itu mendapat dukungan dari Wakil Gubernur, Rahimin Kacong, yang sedang mencari dukungan pemilih Muslim untuk memenangkan pemilihan kepala daerah pada bulan Maret 2006. Rumor yang muncul di masyarakat adalah pembangunan Masjid Raya itu akan disertai dengan Islamic Center yang terbesar di Asia Tenggara. ${ }^{9}$ Hal yang memperkeruh adalah, Rahimin Kacong memainkan kartu agama dengan menjanjikan pemberian IMB apabila ia terpilih

${ }^{8}$ Wawancara penulis dengan tokoh-tokoh agama Kristen di Papua, 2007.

${ }^{9}$ Lihat "Indonesia: Comunal Tension in Papua", Asia Report, No.154 (16 Juni 2008). 
sebagai wakil Gubernur Papua Barat. Ini membuktikan bahwa konflik agama di Papua ternyata tidak bisa dilepaskan dari pengaruh negatif politisasi agama, yang merugikan agamaagama itu sendiri.

Bagi pemimpin-pemimpin gereja Papua, pembangunan Mesjid Raya itu bertentangan dengan kondisi Manokwari yang sejak lama diakui sebagai Kota Injil, sekalipun sebutan Kota Injil itu belum diformalkan. Masjid Raya yang besarnya melampaui gereja-gereja yang pernah ada di Manokwari dikhawatirkan akan merusak keindahan Manokwari sebagai Kota Injil. Apalagi usaha tersebut ternyata melibatkan pejabat pemerintahan daerah. Penolakan umat Kristen terhadap pembangunan Masjid Raya juga didasarkan pada kenyataan bahwa umat Muslim di Manokwari tidak sedang kekurangan tempat untuk beribadah. Pada hari-hari raya besar umat Muslim memang menggunakan lapangan-lapangan sepak bola sebagai tempat beribadah seperti misalnya untuk merayakan Idul Fitri, namun kebiasaan ini bukan karena tempat-tempat ibadah Muslim tidak cukup untuk menampung umat Muslim beribadah, tetapi karena pada hari raya Idul Fitri umat Muslim dari berbagai tempat biasanya beribadah bersama. Namun pada hari-hari biasa kebutuhan itu tidak ada, masjid-masjid yang ada di Manokwari cukup untuk menampung umat muslim beribadah.

Pdt. Albert Yoku, wakil Sekretaris Sinode GKI (Gereja Kristen Injili di Tanah Papua), di Sentani, Jayapura. Menjelaskan, "persiapan untuk membangun Mesjid Raya dan Islamic Center itu sudah dikerjakan sejak 2003-2004. Padahal, di 
Kota Manokwari setiap tahun ada perayaan besar agama Kristen yang dirayakan setiap 5 Februari, hari perayaan masuknya Injil ke Tanah Papua yang dipusatkan di Pulau Mansinam. Sejarah melaporkan bahwa dua orang missionari Jerman, pada tanggal 5 Februari 1855, bernama Johann Gottlob Geissler dan Carl Wilhelm Ottow ketika pertama kalinya menjejakkan kaki di Pulau Mansinam, pulau yang berada di Kabupaten Manokwari, kedua missionari itu mengucapkan kata-kata penting yang sampai saat ini dipegang oleh masyarakat Kristen Papua, "Im Namen Gottes betreten wir dieses Land" "Dengan nama Tuhan kami menginjak tanah ini. ${ }^{10}$

Pernyataan dua missionari yang digelari "Rasul Papua" itu oleh masyarakat Kristen Papua dipercaya sebagai suatu penetapan Tuhan untuk Papua, yaitu sebagai tanah milik Tuhan, yang kemudian mereka sebut Kota Injil atau daerah Injil, karena Manokwari adalah pintu gerbang masuknya Injil ke Tanah Papua. Perayaan masuknya Injil ke Tanah Papua dirayakan oleh orang Kristen Papua. Mereka biasanya, dari berbagai daerah di Papua, tumpah ruah di Pulau Mansinam. Pemerintah juga ikut terlibat memberikan bantuan dalam penyelenggaraan acara akbar itu. Tokoh-tokoh agama Papua menyesalkan, "mengapa di tempat itu harus dibangun Mesjid Raya yang besarnya melampaui gereja-gereja yang ada di Kota Manokwari."11

${ }^{10}$ Lihat B. Dimara, et al., Sejarah 52 Tahun GKI Sesudah 152 Tahun Zending di Mansinam, Tanah Papua (Jakarta: Yayasan Triton Papua, 2007).

${ }^{11}$ Lihat Binsar A. Hutabarat, "Perda Agama (Injil) dalam Perspektif 
Mayoritas Kristen Papua memiliki pandangan yang sama dengan Pdt. Albert Yoku, bahwa mereka merasa terpinggirkan karena perayaan-perayaan besar mereka akan ditelan kemeriahan kehadiran Masjid Raya, dan mereka menjadi khawatir dengan masa depan anak-anak mereka yang senantiasa diperhadapkan dengan simbol-simbol agama Islam, sedang pada sisi yang lain simbol-simbol agama Kristen makin terpinggirkan.

GKI adalah gereja yang dapat dikategorikan sebagai gereja yang cukup toleran, namun pertumbuhan umat Muslim yang mencengangkan di Papua ternyata telah melahirkan hegemoni Islam yang termanifestasi dalam pembangunan masjid yang besarnya melampaui rumah-rumah ibadah Kristen. Hal itu mengancam eksistensi Kristen Papua, termasuk GKI. Umat Kristen menganggap pendirian Masjid Raya adalah wujud intoleransi umat Muslim Papua yang memarginalkan Kristen Papua. Tokoh-tokoh agama di Papua menjadi semakin terancam ketika mengetahui, kemudahan yang selama ini diberikan kepada umat Muslim ternyata tidak sama dengan yang dialami oleh umat Kristen di daerah-daerah lain. Laporan jumlah gereja yang terbakar atau dirusak juga dilaporkan kepada masyarakat Kristen di Papua. Gema Indonesia sebagai negara juara pembakaran rumah ibadah telah menimbulkan perasaan terancam umat Kristen Papua yang terkenal amat toleran. Mereka khawatir, diskriminasi yang menimpa umat Kristen di berbagai daerah pada gilirannya juga akan menimpa

Kristiani", Jurnal Perempuan, Vol. 60 (2008). 
umat Kristen di Papua.

Minimnya promosi dan pembicaraan tentang Pancasila sebagai dasar negara dan dasar hidup bersama Masyarakat Indonesia pada era Reformasi menimbulkan kekhawatiran yang amat mendalam. Masyarakat Papua beranggapan bukan mustahil Pancasila akan hanya tinggal slogan yang tidak lagi diakui sebagai cara pandang bangsa Indonesia yang harus mewujud dalam kehidupan semua warga negara Indonesia. Kondisi itu menyebabkan tokoh-tokoh agama di Papua berusaha untuk memproteksi diri dengan menghadirkan Perda Kota Injil. Tekad masyarakat Kristen Papua untuk menghadirkan Perda Kota Injil tak bisa dipisahkan dari demonstrasi menolak kehadiran Masjid Raya di Kota Manokwari pada 17 November 2005. Ribuan pendemo (ada kira-kira 5.000 orang lebih) memprotes pembangunan Masjid Raya di Manokwari. Ribuan massa yang terdiri dari mahasiswa Kristen, warga gereja dan pemimpin-pemimpin gereja yang berasal dari 30 denominasi gereja, berdemonstrasi ke kantor DPRD Provinsi Papua Barat. Mereka berkumpul di GKI Maranatha, dekat kompleks DPRD, kemudian dengan berjalan kaki mereka tumpah ruah di gedung DPRD kabupaten Manokwari. Mereka diterima oleh Ketua DPRD Provinsi Papua Barat dengan didampingi Bupati Manokwari, Dominggus Mandacan, dan Kapolres dan Dandim setempat. Pada waktu itu juga para pendemo mendesak untuk menetapkan Manokwari sebagai Kota Injil.

Mereka menuntut, pembangunan tempat-tempat ibadah mesti memperhatikan keberadan Manokwari sebagai Kota Injil, 
dan juga peristiwa pembangunan Masjid Raya yang menimbulkan rasa terancam umat Kristen itu tidak boleh terulang lagi. Atas dasar kecurigaan bahwa usaha pembangunan Masjid Raya akan terus diupayakan dengan segala cara, para pendemo kemudian menuntut agar Manokwari ditetapkan sebagai Kota Injil secara formal. Sebutan Manokwari Kota Injil menurut tokoh-tokoh agama di Papua dapat disamakan dengan sebutan "Jombang Kota Santri", atau "Aceh Serambi Mekkah", namun karena penetapan Manokwari Kota Injil terkait usaha "membendung" misi Islam di Papua, maka penetapan Manokwari sebagai Kota Injil telah menimbulkan perasaan terdiskriminasikan umat Islam Papua, dan juga umat Islam yang berada di seantero Indonesia.

Penetapan Manokwari sebagai Kota Injil ternyata tidak cukup memuaskan tokoh-tokoh agama Kristen di Papua. Mereka berpendapat, masyarakat Papua, khususnya mereka yang beragama Kristen ternyata belum memiliki komitmen yang kuat untuk hidup sesuai dengan Injil. Padahal, pada saat yang sama arus migrasi ke Papua telah mengubah wajah Papua yang mulanya memiliki populasi Kristen lebih tinggi, dan kini dengan adanya migrasi penduduk yang beragama Islam, populasi muslim di Papua bertambah dengan pesat, khususnya pada kota-kota besar. Penduduk muslim yang datang dengan membawa simbol-simbol agama itu kemudian mengubah wajah kota Manokwari, yang kemudian dipenuhi dengan atribut-atribut muslim.

Tokoh-tokoh agama Papua kemudian bergerak lebih jauh dengan mengusulkan aturan-aturan yang dapat dituangkan 
dalam bentuk Perda yang bersifat memaksa orang Kristen untuk hidup selaras dengan aturan Injil demi melestarikan Manokwari sebagai Kota Injil sebagaimana layaknya PerdaPerda syariah yang memaksa umat muslim menaati syariah. Kota Manokwari sebagai Kota Injil mutlak dipenuhi dengan simbol-simbol kekristenan, bukan simbol agama-agama lain. Selang beberapa bulan setelah aksi demo penolakan pembangunan Masjid Raya, lahirlah Perda Miras (larangan minuman keras) pada bulan Desember 2006. ${ }^{12}$ Perda tersebut ditetapkan dalam usaha untuk mengukuhkan keberadaan Manokwari sebagai Kota Injil. Perda itu diakui berisi nilai-nilai Injil, karena penggagasnya adalah komunitas Kristen, dalam hal ini gereja-gereja. Namun, nilai-nilai itu juga dapat diterima oleh umat beragama lain, karena memang nilai-nilai itu diakui bersifat universal.

Perda Miras mendapat sambutan hangat dari masyarakat Manokwari, karena dengan hadirnya Perda Miras, keamanan di Manokwari menjadi lebih baik, gangguan para pemabuk yang biasanya hadir pada malam hari sebelum diberlakukannya Perda Miras, menurun secara drastis. Manokwati menjadi kota yang nyaman untuk pendatang, juga bagi penduduk yang ingin berjalan-jalan di malam hari, demikian juga bagi mereka yang biasa berdagang pada malam hari. Karena itu, kelahiran Perda larangan minuman keras itu dianggap cukup efektif untuk

${ }^{12}$ Lihat, Peraturan Daerah Kabupaten Manokwari Nomor 05 Tahun 2006 tentang Larangan Pemasukan, Penyimpanan, Pengadaan dan Penjualan Minuman Beralkohol. 
menjaga keindahan Kota Manokwari sebagai Kota Injil.

Pada tanggal 1-2 Februari 2007, dalam rangka memperingati 152 tahun masuknya Injil di Papua, diadakanlah seminar dan lokakarya atas kerja sama Pemda Manokwari, Universitas Cendrawasih (UNCEN), STT-GKI dan Universitas Papua (UNIPA), yang dihadiri oleh tokoh-tokoh gereja dari berbagai denominasi, tokoh perempuan dan pemuda, bertempat di Gereja Kristen Injili Elim Kuali, yang dibuka oleh Bupati Manokwari, Dominggus Mandacan. ${ }^{13}$ Pada akhir seminar itu diajukanlah usulan "Raperda Pembinaan Mental dan Spiritual" untuk Manokwari sebagai daerah Injil, dan lebih dikenal dengan sebutan "Perda Manokwari Kota Injil”. Usulan tersebut dituangkan dalam format yang berbentuk Perda, dan kemudian menyebar tanpa diketahui siapa yang menyebarkannya, berita itu menjadi laporan utama di mediamedia massa.

Manokwari yang terletak jauh di ujung timur itu menjadi buah bibir bukan hanya di Indonesia, tetapi juga di luar negeri, karena radio Nederland juga pernah mewawancarai tokohtokoh masyarakat Papua, dan isinya beredar luas di media massa, dan karena penyebaran berita yang begitu cepat, meski Raperda Injil itu baru wacana, baru berupa usulan masyarakat Kristen Papua tentang bagaimana melindungi moral masyarakat, kehadiran usulan tokoh-tokoh agama Kristen perihal bagaimana menata Manokwari sebagai daerah Injil itu

${ }^{13}$ Sambutan Bupati Manokwari, Pembukaan Lokakarya, Perayaan Hari Ulang Tahun Ke-152 Pekabaran Injil di Tanah Papua, 1 Februari 2007. 
telah melahirkan kontroversi. Kekhawatiran bahwa usulan tokoh-tokoh agama Kristen tersebut akan diterima pemerintah daerah dan dituangkan dalam bentuk Perda sangat beralasan, karena penduduk Manokwari mayoritas beragama Kristen. Apalagi, sebanyak 20 dari 25 anggota DPRD Manokwari ketika Perda itu dimunculkan diketahui memeluk agama Kristen.

Pada bulan Mei 2008 pemerintah daerah Manokwari kemudian mengakomodasi usulan tokoh-tokoh agama Kristen tersebut, dan lahirlah "Raperda Tentang Penataan Manokwari Sebagai Kota Injil."14 Meski Raperda ini berbeda dari draft usulan tokoh-tokoh agama Kristen, dan isinya lebih kurang diskriminatif, ${ }^{15}$ Raperda tentang Penataan Manokwari Sebagai Kota Injil itu ternyata kandas di tangan DPRD Manokwari. Namun, kegagalan menghadirkan Perda tentang Penataan Manokwari Kota Injil sesungguhnya tak pernah sirna di hati pendukung Perda Manokwari Kota Injil, apalagi jika perlakuan diskriminatif berupa pembakaran, perusakan, dan penutupan gereja terus terjadi di daerah-daerah mayoritas Islam di negeri ini, dan pemerintah terus membiarkannya, atau bahkan terlibat langsung dalam kegiatan tersebut.

14 Raperda Tentang Penataan Manokwari Sebagai Kota Injil, 2008.

${ }^{15}$ Lihat Raperda Penataan Kota Injil, 2008. Misalnya, dalam Raperda Penataan Kota Injil 2008, larangan penggunaan jilbab tidak dituliskan. 


\section{PANDANGAN TEOLOGI KRISTEN TERHADAP PERDA MANOKWARI KOTA INJIL}

Pemisahan antara negara dan gereja (agama) merupakan sesuatu yang harus ada menurut sudut pandang kristiani, karena negara dan agama memiliki kodrat yang berbeda. Yesus secara tegas juga mengatakan "Berikanlah kepada Kaisar apa yang wajib kamu berikan kepada Kaisar dan kepada Allah apa yang wajib kamu berikan kepada Allah (Lukas 20:25)". Selanjutnya dalam Roma 13:1-7, dijelaskan mengenai kekuasaan dari negara di mana tugas negara adalah untuk menegakkan keadilan Allah dalam rangka pemeliharaan dunia. Negara mendapatkan wewenang dari Allah dan harus bertanggung jawab kepada Allah. Singkatnya, fungsi negara adalah sebagai alat Allah untuk menghukum kejahatan, dan mengusahakan kebaikan bagi seluruh rakyat. Kemudian untuk melaksanakan fungsinya itu negara diberi wewenang untuk memaksa. Gereja harus tunduk kepada wewenang negara yang diberikan oleh Allah, namun ketundukan gereja kepada negara bukanlah ketundukan tanpa batas, karena gereja hanya tunduk kepada pemerintah sepanjang negara menjalankan wewenangnya dengan baik, dan negara tidak boleh menghalangi gereja untuk menjalankan panggilannya yang telah ditetapkan oleh Allah, dan negara juga tidak boleh memasuki wewenang gereja yang bersumber dari Allah.

Mengenai keterpisahan antara gereja dan negara ini, Christian de Jonge menyarikan pandangan Agustinus dalam bukunya De Civitate Dei seperti berikut: 
Gereja di dunia ini adalah persekutuan semua warga negara Allah yang sedang menuju ke keselamatan surgawi dan gerejalah yang melayankan kepada anggotanya semua yang perlu untuk keselamatan itu, yaitu Firman dan sakramensakramen. Negara pada dasarnya dinilai negatif, karena negara, berbeda dengan gereja, tidak didasarkan kasih, melainkan pada kuasa. Manusia yang berdosa memakai kuasa biasanya untuk tujuan yang jahat, yaitu penindasan sesama manusia. Akan tetapi sejak keselamatan dinyatakan dalam dunia, negara pun dapat melakukan sesuatu yang positif, yaitu mempergunakan kuasanya untuk melindungi orang yang baik terhadap orang yang jahat dan mengendalikan kuasa dosa. Oleh sebab itu pemerintahan Kristen dapat ikut menyumbang kepada kemajuan negara Allah. ${ }^{16}$

Dalam pandangan Kristen gereja merupakan sesuatu yang terpisah dari negara, namun keterpisahan tersebut bukanlah keterpisahan total, sehingga negara menjadi negara yang sekuler, di mana agama dimasukkan dalam dunia privat. Tetapi gereja harus memberikan sumbangsih dalam menjaga tugas negara untuk menjalankan tugasnya dengan baik, sebagaimana yang diberikan oleh Allah, namun gereja tidak dapat menguasai negara, karena negara dan gereja mempunyai wewenang yang berbeda dan bersumber dari Allah, keduanya sama-sama bertanggung jawab kepada Allah sang pemberi

${ }^{16}$ Christian de Jonge, Apa itu Calvinisme? (Jakarta: BPK Gunung Mulia, 1998), 264. 
wewenang tersebut.

Perbedaan antara wewenang gereja dan negara dalam prakteknya tidak selalu berjalan dengan mulus. Karena negara dan gereja sama-sama menuntut ketaatan dan komitmen yang total dari warganya. Problem terjadi ketika kedua kekuatan besar yang menuntut ketaatan mutlak tersebut bersinggungan. Untuk menghindari terjadinya pemasungan kebebasan manusia dalam persinggungan tersebut ada beberapa pola yang ditempuh oleh manusia. Pertama, pemisahan mutlak antara agama dan negara. Kedua, menundukkan yang satu dengan yang lainnya, dalam bentuk agama negara (agama tunduk kepada negara) atau dalam bentuk negara agama (negara tunduk pada agama). ${ }^{17}$

Pola-pola sebagaimana dijelaskan di atas terjadi dalam perjalanan sejarah dalam hubungan antara negara dan gereja. Pola hubungan gereja yang berada di atas negara nyata dalam Tradisi Katolik Roma yang memahami eksistensi negara bersumber pada hukum kodrat, dimana pada hakekatnya gereja dan negara adalah dua entitas yang otonom, baik gereja maupun negara mempunyai kekuasaan yang berbeda. Secara institusional yang satu tidak menguasai yang lain. Walaupun gereja dan negara terpisah, keduanya sering kali bersinggungan. Keduanya tidak mungkin terpisah secara total karena orang-orang yang sama adalah warga negara dan juga warga gereja. Memang hukum negara adalah wewenang

17 Eka Darmaputera, Pergulatan Kehadiran Kristen (Jakarta: BPK Gunung Mulia, 2001), 130. 
negara, namun isi dari hukum tersebut terkait erat dengan kepentingan gereja. Sehingga dalam situasi tersebut ada pertentangan siapa yang memegang kekuasaan dalam masyarakat Kristen. Dan pada waktu itu warga gereja secara bersamaan adalah warga negara. Karena kepentingan gereja terhadap isi hukum negara, maka gereja menuntut kuasa atas negara. gereja menundukkan negara di bawahnya. ${ }^{18}$

Tuntutan gereja untuk mempunyai kuasa atas negara merupakan penyimpangan dari wewenang gereja, akibatnya terjadi pengekangan kebebasan manusia, karena kekuasaan gereja yang berada di atas negara membuat kekuasaan menjadi absolut, dan mengabaikan semua yang berbeda dari gereja. Hal tersebut terjadi karena sejak jatuh ke dalam dosa, manusia tidak dapat melaksanakan hukum kodrat secara sempurna. Seharusnya keterlibatan gereja dalam negara tidak didasarkan untuk menguasai negara, tetapi untuk menolong negara berlaku sesuai dengan kodratnya. Namun demi mempertahankan eksisitensinya, karena gereja mempunyai kepentingan dengan hukum-hukum negara, maka menguasai negara merupakan godaan yang tidak mudah bagi gereja yang memasuki dunia politik. Kekuasaan gereja yang melampaui batas wewenangnya ini mengakibatkan terjadinya pengekangan terhadap kebebasan manusia, terutama terjadi dalam abad pertengahan. ${ }^{19}$

18 Ibid., 148.

${ }^{19}$ Lihat De jonge, Apa Itu Calvinisme? 264-266. 
Perubahan hubungan antara gereja dan negara terjadi pada pemikiran Reformasi. Apabila tradisi Roma Katolik melihat eksistensi negara bersumber dalam hukum kodrat, maka reformasi melihat negara dalam persfektif kejatuhan manusia. Artinya, dalam usaha memelihara dunia yang telah jatuh dalam dosa. Allah menciptakan institusi negara sebagai bagian dari ordo pemeliharaan. Jadi negara tidak termasuk dalam ordo penciptaan, sehingga negara sebagaimana pandangan Agustinus dilihat secara negatif walaupun tidak berarti bahwa negara tidak berguna. Bagi Luther institusi negara dalam dirinya bersifat negatif karena negara tidak menghasilkan kebaikan, ia hanya untuk mencegah kejahatan. Dan kekuasaan negara sering kali mudah untuk diselewengkan, namun demikian negara perlu ada untuk menghindari anarki, karena bagi Luther tirani lebih baik dari pada anarki. ${ }^{20}$

Dalam teori dua kerajaannya Luther menggambarkan bahwa negara dan gereja adalah memiliki kewenangan yang berbeda. Negara mempunyai wewenang dalam urusan kesejahteraan, sedang gereja dalam urusan-urusan spiritual. Dan gereja tidak boleh melawan pemerintah, kecuali negara mencampuri urusan gereja dalam wewenang spiritual. Sedangkan pada waktu negara bertindak sewenang-wenang dalam menjalankan kewajibannya, gereja tidak boleh melawan negara, tetapi sebaliknya gereja demi ketaatan pada Allah rela untuk menderita. Pandangan Luther ini tampak kurang

${ }^{20}$ Darmaputera, Pergulatan Kehadiran Kristen, 149. 
memerhatikan peran sosial gereja. Pola hubungan ini merupakan pemisahan negara dan gereja secara total. Pola hubungan antara gereja dan negara, Luther membuat gereja menjadi pasif, bahkan akibatnya gereja menjadi tidak perduli dengan hal-hal dunia, yang seharusnya menjadi tanggung jawabnya. Hubungan antara gereja dan negara sebagaimana pandangan Luther mengakibatkan negara bertindak melampaui daerah kekuasaannya. Dan walaupun negara bertindak melampaui wewenangnya, gereja tetap harus tunduk kepada negara.

Pandangan Calvin mengenai negara lebih positif dibandingkan pemahaman Luther, walaupun Calvin juga setuju untuk melihat negara dalam persfektif kejatuhan manusia. Mengenai hal ini Abrahama Kuyper menerangkan demikian:

Sebab sesungguhnya tanpa dosa pasti tidak akan ada tatanan penguasa dan negara;... Dengan demikian, semua konsepsi yang benar tentang nature negara dan tentang pengambilalihan kekuasaan oleh pemerintah, dan di pihak lain, semua konsepsi yang benar tentang hak dan kewajiban rakyat untuk mempertahankan kemerdekaan, bergantung pada apa yang telah dikedepankan oleh Calvinisme sebagai kebenaran primordial - bahwa Allah telah membentuk orang-orang yang memerintah, karena alasan dosa...tanpa hukum dan pemerintahan, dan tanpa otoritas yang berkuasa, akan sungguh-sungguh menjadi neraka di bumi, atau setidaknya merupakan suatu pengulangan dari apa yang pernah ada di 
bumi ketika Allah menenggelamkannya dalam air bah, ras pertama manusia yang bobrok. ${ }^{21}$

Menurut pandangan Calvin negara ada karena manusia telah jatuh ke dalam dosa. Tanpa dosa negara tidak perlu ada. Namun walaupun Calvin melihat negara secara negatif, tapi ia percaya bahwa negara berguna agar dapat mengatur kehidupan menjadi baik. Calvin melihat negara lebih positif dibandingkan Luther. Dalam pandangan Calvin tanpa negara kehidupan menjadi seperti neraka. Walaupun Calvin mengakui ada kedaulatan yang berbeda antara negara dan agama sebagaimana Luther, namun berbeda dengan Luther, Calvin berpendapat bahwa apabila negara menyalahgunakan kekuasaannya, baik urusan spiritual maupun dunia, rakyat boleh melawannya. Jadi Calvin tidak memisahkan negara dengan agama secara total, ia mengakui pemisahan tetapi tidak ada keterpisahan. Tidak ada subordinasi atau separasi total, melainkan yang terjadi adalah koordinasi. ${ }^{22}$ "Kedaulatan negara dan kedaulatan gereja berdiri berdampingan, dan mereka saling membatasi satu dengan lainnya"23. Pandangan Calvin ini didasarkan oleh pemahaman bahwa gereja dan negara memperoleh wewenangnya dari Allah yang satu, bagi dunia yang satu dan kemanusiaan yang satu. ${ }^{24}$ Bagi Calvin

${ }^{21}$ Abraham Kuyper, Ceramah-Ceramah Mengenai Calvinisme (Jakarta: Momentum, 2005), 90-91.

22 Darmaputera, Pergulatan Kehadiran Kristen, 151.

${ }^{23}$ Kuyper, Ceramah-Ceramah Mengenai Calvinisme, 122.

${ }^{24}$ Lihat Darmaputra, Pergulatan Kehadiran Kristen, 144-152. 
pemerintahan sipil merupakan sesuatu yang dibutuhkan karena dosa masih merajalela. Negara ada karena manusia cenderung berbuat kejahatan, bahkan di dalam masyarakat Kristen sendiri banyak orang yang tidak menjadi Kristen yang sejati. Karena wewenang negara berasal dari Allah, maka negara harus beralaskan pada penghormatan dan kesusilaan. Jadi negara bertanggung jawab terhadap kemajuan agama, untuk menjaga kesusilaan, namun negara tidak diberi hak untuk mengatur apa yang terjadi dalam gereja. ${ }^{25}$

Berdasarkan uraian tentang hubungan gereja dan negara menurut pandangan Calvin, maka tampak bahwa pemikiran Calvin tentang hubungan gereja dan negara merupakan pemikiran yang sangat menyeluruh dari Alkitab, dalam arti dalam hubungan tersebut gereja dapat menjalankan perannya dengan optimal, baik dalam kehidupan spiritual maupun dalam pengelolaan alam untuk membawa kesejahteraan manusia. Pemikiran Calvin tentang hubungan negara dan gereja merupakan kebenaran yang alkitabiah dan bersifat inklusif, dalam arti tidak hanya cocok dalam komunitas Kristen, tetapi juga dalam komunitas yang beragam agama. Dan penerapan dari hubungan negara dan gereja/agama akan memberikan kebebasan kepada individu yang ada, secara khusus dalam penghormatan kebebasan beragama. Hal tersebut tampak jelas dalam pemilihan sistem pemerintahan yang diajukan oleh Calvin, di mana ia berpendapat bahwa dalam suatu sistem pemerintahan sebaiknya kuasa tertinggi

${ }^{25}$ De Jonge, Apa itu Calvinisme?, 270. 
dalam negara tidak berada dalam tangan satu orang, melainkan ditanggung dalam kelompok yang lebih luas (aristokrasi) atau lebih baik lagi suatu kelompok yang dipilih oleh rakyat. Jadi Calvin mengusulkan aristokrasi dan demokrasi. ${ }^{26}$ Tidaklah mengherankan jika Calvin disebut sebagai pionir kebebasan hati nurani dan HAM. Karena pemerintahan di tangan banyak orang dan berada dalam pengawasan banyak orang merupakan sistem negara yang disulkan Calvin, dan dalam sistem itu kebebasan individu dapat terjaga.

Mengenai pemerintahan yang sesuai dengan pandangan kristiani ini, John Stott secara lebih tegas mengatakan:

Jadi, demokrasi mencerminkan pandangan alkitabiah yang seimbang tentang manusia, sebagaimana memang layak diharapkan mengingat tempat persemaiannya, yaitu di Eropa yang Kristiani pada jaman Pasca Reformasi. Demokrasi juga menyediakan peluang bagi orang Kristen untuk memberikan sumbangsihnya yang konstruktif dalam suatu masyarakat yang pluralistik. ${ }^{27}$

Namun demokrasi sebagai sistem pemerintahan banyak orang dengan pengawasan banyak orang ini bukanlah sesuatu yang mudah dibangun, tetapi demokrasi merupakan kebutuhan yang memungkinkan negara tidak menjadi gurita yang menguasai seluruh bidang kehidupan, mengenai

26 Ibid., 281.

${ }^{27}$ John Stott, Isu-Isu Global (Jakarta: Yayasan Komunikasi Bina Kasih, 1984), 76. 
kesulitan membangun demokrasi ini Stephen Tong menjelaskan demikian:

\begin{abstract}
Demokrasi adalah bagaikan seorang bayi di dalam kandungan yang sulit untuk dilahirkan. Demokrasi menempuh jalan yang lama dan sulit sekali. Bagaikan suatu kehamilan yang sudah amat tua dan sulit dilahirkan. Terkadang, kelahiran demokrasi mengkibatkan luka yang berat bagi induknya dan kematian yang banyak bagi rakyatnya, dan menjadi suatu kecelakaan besar bagi jaman itu. Namun demikian demokrasi tetap harus dilahirkan. ${ }^{28}$
\end{abstract}

Bentuk negara demokrasi yang memberikan jaminan wewenang negara yang terbatas, yang memungkinkan adanya kebebasan individu dapat terjaga, merupakan sistem pemerintahan yang tidak mudah dilaksanakan. Namun dalam negara demokrasi kebebasan beragama umumnya lebih dapat terjaga demikian juga dalam negara demokrasi yang mengakui hak-hak individu, pluralisme agama dan sekularisasi yang tidak berpihak pada agama tertentu, memungkinkan usaha untuk mengawal kebijakan pemerintah dalam menegakkan hukum yang adil melibatkan peran serta seluruh masyarakat. Tidak mengherankan dalam negara demokrasi, proteksi HAM lebih terjaga, walaupun tidak selalu demikian. Karena proses melahirkan suatu demokrasi menuntut perjuangan yang amat

28 StephenTong, Iman Penderitaan dan Hak Asasi Manusia, (Jakarta:

Momentum, 1996), 16. 
sulit, bahkan mungkin harus mengorbankan nyawa yang tidak sedikit. Dalam negara demokrasi yang tidak menghargai pluralisme agama, kebebasan beragama seringkali tetap terbelenggu, karena adanya usaha agama untuk memiliki akses yang lebih besar dalam pemerintahan dan kemudian mendominasi negara. Jadi bisa saja jika demokrasi tidak dijaga akan menimbulkan penyelewengan kekuasaan, di mana demokrasi hanya sekadar slogan, namun pada prakteknya bukan negara demokrasi.

Dengan segala kesulitan yang ada, sistem pemerintahan demokrasi menjadi pilihan utama bagi penegakan kebebasan beragama. Karena pemerintahan banyak orang, memungkinkan orang-orang yang beragam (terdiri banyak agama) yang memiliki hak yang sama dan saling menjaga hakhak sesamanya. Kontrol dari banyak orang lebih memungkinkan kebebasan beragama dapat terwujud, maka tindakan diskriminasi dapat diminimalisir.

Pemisahan antara negara dan agama, karena wewenang yang berbeda dari negara dan agama, akan menciptakan hubungan koordinasi, di mana keduanya saling menjaga untuk menjalankan wewenangnya dengan benar. Koordinasi dalam hubungan antara negara dan agama harus terjadi karena keduanya memiliki wewenang dari sumber yang sama yaitu Allah yang satu, bagi dunia yang satu, dan kemanusiaan yang satu. Hubungan antara negara dengan agama sebagaimana dinyatakan oleh Calvin di atas akan membawa kesadaran bahwa kekuasaan negara berasal dari Tuhan dan harus menjalankan fungsinya sesuai apa yang telah Tuhan tetapkan, 
di mana negara harus menjaga institusi agama yang ada di dalamnya, termasuk individu-individu untuk tidak melampaui batas kekuasaan mereka, sehingga tidak terjadi pembelengguan terhadap hak-hak institusi atau individu lain. Negara dapat melaksanakan kewajibannya dengan baik apabila memiliki toleransi terhadap religious pluralism. ${ }^{29}$ Dan secara bersamaan negara juga harus menjamin kedaulatan individu (sovereignty of individual person), karena setiap individu berkedudukan sebagai seorang raja dalam hati nuraninya, kecuali dari semua kewajiban-kewajibannya. ${ }^{30}$ Manusia yang memiliki "absolut liberty of conscience" baik untuk berganti agama atau memeluk agama yang ia inginkan sebagaimana dinyatakan dalam Deklarasi Universal HAM, harus mendapat perlindungan dalam pemenuhan hak-haknya. Dan pengakuan adanya kedaulatan individu ini merupakan hak asasi yang paling utama, dan hak itu dilindungi dalam negara demokrasi. Jadi negara harus menjaga hak-hak ini. Penghormatan terhadap hak-hak individu ini merupakan tanda bahwa ada proteksi HAM dalam suatu negara. Dalam hubungan negara dan agama, Alkitab telah memberikan batasan yang tegas, namun dalam perjalanannya gereja terkadang tidak konsisten untuk berpegang pada kebenaran yang diajarkan oleh Alkitab. Lebih tepatnya dalam persinggungan antara gereja dan negara, muncul kompromi-kompromi yang bertentangan dengan Alkitab, namun, terciptanya kompromi yang menyimpang

${ }^{29}$ Lihat Kuyper, Ceramah-Ceramah Mengenai Calvinisme, 88-125.

${ }^{30}$ Ibid., 123. 
tersebut adalah karena kelemahan manusia, bukan karena Alkitab tidak memberikan arah yang pasti. Karena itu perjuangan Kristen dalam memberikan kontribusinya dalam masyarakat memerlukan keteguhan untuk tetap berpegang pada kebenaran dalam kebergantungan kepada Allah.

Dengan demikian jelaslah menurut pemikiran Kristen, undang-undang yang menaungi kehidupan orang banyak itu harus berisi nilai-nilai yang bersifat universal, atau nilai-nilai kebaikan bersama. Di sana tidak ada pembenaran terhadap diskriminasi agama, semua agama berhak untuk memberikan kontribusinya, dan agama-agama harus mendorong agamaagama lain untuk dapat memberikan kontribusi bersama dalam pembentukan undang-undang.

Berdasarkan uraian di atas dapat dipahami bahwa apa yang dimuat dalam draft Raperda Pembinaan Mental dan Spiritual yang kemudian berubah menjadi Draft Raperda Injil, atau Penataan Manokwari Sebagai daerah Injil, bukan hanya isinya yang tidak sesuai dengan pandangan iman Kristen. Tapi keberadaan Perda Injil itu sendiri bertentangan, karena itu merupakan hegemoni agama Kristen terhadap agama-agama lain. Agama berusaha memakai negara untuk kepentingan privat agama, dan akibatnya akan melahirkan diskriminasi terhadap agama-agama lain.

\section{KONSEKUENSI BAGI GEREJA-GEREJA DI INDONESIA}

Usulan tokoh-tokoh agama Kristen Papua yang dituangkan dalam bentuk "Raperda Pembinaan Mental dan Spiritual" untuk Manokwari sebagai Kota Injil pada awalnya 
belum bisa disebut sebagai Raperda. Namun, setelah pemerintah daerah Manokwari menerima usulan tokoh-tokoh agama Kristen Papua tersebut dan dituangkan dalam "Raperda Tentang Penataan Manokwari sebagai Kota Injil,"yang lebih dikenal dengan Perda Manokwari Kota Injil atau Perda Injil, terlihat jelas bahwa usulah tokoh-tokoh agama Kristen Papua menjadi inti dari isi "Raperda Tentang Penataan Manokwari sebagai Kota Injil." Meski isinya lebih kurang diskriminatif dibandingkan usulan tokoh-tokoh agama Kristen Papua, Raperda itu tetap saja mendiskriminasikan agama-agama lain, dan bisa digolongkan pada Perda bernuansa agama walau tidak secara-terang-terangan menyebut diri sebagai Perda agama Kristen. Tapi, karena pengusulnya adalah tokoh-tokoh agama Kristen (gereja), maka kehadiran Perda tersebut memiliki konsekuensi bukan hanya bagi gereja-gereja di Papua, tapi juga terhadap kehadiran gereja-gereja di seantero Indonesia.

Draft berupa usulan pemimpin-pemimpin gereja Papua itu, khususnya Gereja Kristen Injili di tanah Papua, sebagai pelopor utama yang juga kemudian mengikutsertakan gerejagereja lainnya, diakui memiliki pasal-pasal yang dianggap diskriminatif. Adanya pasal-pasal yang diskriminatif tersebut diakui dengan jujur baik oleh tokoh-tokoh agama di Papua yang telah membaca isi draf tersebut, khususnya Badan Kerja Sama Gereja (BKSG), dan juga pejabat di Kabupaten Manokwari. Kepala Bagian Hukum Manokwari, Robert K. R. Hammar, berkomentar, "Perda Manokwari Kota Injil, usulan awalnya adalah Perda Pembinaan Mental dan Spiritual, jadi itu 
bukan Perda agama, karena tidak mungkin menyamakan nilainilai Injil yang adalah perintah Tuhan, dengan Perda yang adalah buatan manusia, itu justru akan mereduksi nilai Injil itu sendiri." 31 Pemerintah daerah menampung usulan itu dan akan disusun kembali oleh tim legislasi dalam bentuk format Raperda untuk kemudian diadakan pembahasan. Ia juga mengatakan, "dalam Raperda yang akan dibahas itu tentunya tidak akan ada nilai-nilai yang bersifat diskriminatif, tetapi pastilah akan berisi nilai-nilai yang universal yang dapat diterima oleh semua". Apa yang dikatakan Kabag Hukum Manokwari itu terbukti dalam "Raperda Tentang Penataan Manokwari sebagai Kota Injil”yang isinya lebih kurang diskriminatif dibandingkan usulan tokoh-tokoh agama Kristen.

Pendeta Bastian Salabai, salah seorang pembicara dalam semiloka dan yang juga memberikan kontribusi usulan untuk pembuatan Perda pembinaan mental dan spiritual mengatakan, "Aturan yang akan ditetapkan dalam Perda itu adalah nilainilai yang universal, sebagaimana Injil itu berisi nilai-nilai universal, itulah yang kami usulkan. Jika kemudian ada usulanusulan yang tampak berisi nilai-nilai yang diskriminatif itu bisa saja didialogkan, hanya saja memang Perda itu merupakan proteksi terhadap umat Kristen dari usaha-usaha islamisasi yang gencar dilaksanakan di Papua" ${ }^{32}$ Berbeda dari itu, Pdt Sherley, seorang pendeta di Manokwari, berkomentar, "Dalam semiloka yang menggagas usulan Perda kota Injil itu, umat

31 Wawancara penulis dengan nara sumber, 2007.

32 Wawancara penulis dengan narasumber, 2007. 
Kristen yang hadir menyetujuinya, jadi kami rindu membuat suatu Perda yang akan membuat Manokwari sebagai Kota Injil". Ia juga menambahkan, "Indonesia bukan negara Islam, jika di Aceh diizinkan ditetapkan Perda syariah, maka mengapa kami tidak boleh menetapkan Perda Kota Injil, lagi pula Perda Kota Injil berbeda dengan Perda syariah yang diskriminatif, sedang Perda kota injil tidak bersifat diskriminatif" ${ }^{33}$

Dengan demikian jelaslah kehadiran Perda Manokwari Kota Injil ternyata telah memosisikan gereja ketika menjadi mayoritas cenderung mendiskriminasikan agama-agama lain. Itu terbukti dari pasal-pasal diskriminatif yang tertuang dalam Perda Manokwari Kota Injil, baik berupa larangan melakukan kegiatan publik pada hari Minggu untuk agama-agama lain, pelarangan penggunaan jilbab, pelarangan azan, dan keharusan pemasangan atribut-atribut Kristen pada gedung-gedung pemerintah. $^{34}$

33 Wawancara penulis dengan narasumber 2007.

${ }^{34}$ Lihat Raperda Penataan Manokwari Sebagai Daerah Injil. Pasal 19. Kegiatan penataan diselenggarakan dengan memperhatikan, nilai-nilai sejarah, budaya, adat-istiadat dan kearifan lokal yang berlaku dalam masyarakat lokal, terutama mayoritas orang asli atau penduduk asli Papua yang menganut agama Kristen.(1) Perwujudan nilai-nilai dalam aspek tertentu sebagaimana dimaksud pada ayat (2) dilaksanakan melalui pembangunan dan pemeliharaan situs sejarah, penataan asesoris simbol agama yang bernuansa religius dan kultural serta tata peribadatan dan busana yang bernuansa Kristen. Pasal 20: (1)Dalam rangka penghargaan terhadap nilai-nilai kesejaraan dan kultural sebagaimana dimaksud dalam Pasal 19, Pemerintah Daerah wajib menetapkan penamaan fasilitas publik dengan menggunakan nama para tokoh lokal. (2)Selain penetapan nama fasilitas publik, Pemerintah Daerah wajib menetapkan pemasangan asesoris 
Di samping itu kehadiran Perda Manokwari Kota Injil telah melahirkan kontroversi di dalam Gereja itu sendiri. Kontroversi terjadi antara mereka yang setuju dan mereka yang menolak kehadiran Perda Manokwari Kota Injil. Perda Manokwari Kota Injil bisa menyebabkan terjadinya perpecahan di dalam gereja, bukan hanya di Papua, tetapi juga pada Gerejagereja di luar Papua.

Kehadiran Perda Manokwari Kota Injil jelas mencerminkan adanya kemunduran gereja, yakni adanya ketidakmampuan gereja untuk menafsirkan Injil secara benar,

dan simbol agama Kristen sebagaimana dimaksud dalam Pasal 19 pada tempat-tempat umum dan gedung atau kantor Pemerintahan dan Kantor badan usaha atau badan hukum/kantor lembaga keagamaan. (3)Pemasangan asesoris dan simbol keagamaan sebagaimana dimaksud pada ayat (2) wajib dilakukan oleh setiap orang atau badan/ lembaga keagamaan Kristen. Pasal 22. Setiap orang dan atau badan tidak diperbolehkan melakukan aktivitas publik pada hari Minggu, selain kegiatan peribadatan dan pelayanan rohani. Pasal 23. Selain hari Minggu, Pemerintah Daerah menetapkan hari-hari besar agama Kristen atau hari-hari besar gerejawi sebagai hari libur resmi Daerah. (1)Pada hari raya sebagaimana dimaksud pada ayat (2), setiap orang dan atau badan tidak diperbolehkan melakukan aktivitas publik. Pasal 38. Setiap orang dilarang mempergunakan busana menonjolkan simbol keagamaan di tempat umum, tempat pendidikan, dan kantor Pemerintahan. Dalam naskah akademik Pembinaan Mental dan Spiritual ditetapkan. Dan untuk mencegah terjadinya konflik kepentingan dan konflik sosial maka apabila pada suatu kampung telah ada sarana peribadatan yang diperuntukkan bagi orang asli atau penduduk asli Papua, tidak diperbolehkan dibangun sarana peribadatan bagi penduduk yang menganut agama lain. Hal yang sama berlaku bagi setiap orang atau badan dalam membangun sarana peribadatan berupa mesjid langgar, musolah atau yang disebut dengan nama lain di lingkungan kantor pemerintahan. 
dan kemudian membawanya pada konteks Indonesia. Ini juga membuktikan bahwa gereja ternyata tidak mampu memahami Pancasila sebagai dasar bagi kehidupan bersama, rumah bersama bagi agama-agama yang ada di Indonesia. Gereja bisa dianggap mengingkari nilai-nilai dari Pancasila.

\section{KESIMPULAN}

Harus diakui bahwa kehadiran usulan tokoh-tokoh agama Kristen Papua yang dituangkan dalam bentuk "Raperda Pembinaan Mental dan Spiritual" Untuk Manokwari sebagai Kota Injil berdampak buruk bagi gereja. Penerimaan pemerintah daerah Manokwari terhadap usulan tokoh-tokoh agama Kristen yang dituangkan dalam "Raperda Tentang Penataan Manokwari sebagai Kota Injil,"yang lebih dikenal dengan Perda Manokwari Kota Injil, atau Perda Injil, meski memuat sedikit perubahan tetap saja telah memosisikan gereja sebagai ancaman bagi agama-agama lain.

Perda Penataan Manokwari sebagai Kota Injil meski kurang diskriminatif dibandingkan usulan tokoh-tokoh agama Kristen yang dikenal dalam "Raperda Pembinaan Mental dan spiritual, tetap saja dapat digolongkan dalam Perda bernuansa agama. Karena penetapan Manokwari sebagai Kota Injil secara formal sesungguhnya tidak bisa dilepaskan dari Perda Manokwari Kota Injil. Jadi jika Penetapan Manokwari sebagai proteksi umat Kristen terhadap derasnya islamisasi di Papua, maka Perda tersebut juga merupakan bagian dari strategi umat Kristen untuk membendung misi Islam, termasuk kehadiran Perda syariah. Apabila Perda Manokwari Kota Injil sebagai 
dianggap bagian dari strategi gereja untuk membendung serbuan Perda-Perda syariah, maka strategi tersebut justru merugikan bagi gereja itu sendiri. Gereja terjebak dalam politisasi agama dan agamaisasi politik, demi menuntut kekhususannya dengan mengandalkan kekuatan mayoritas, dan tindakan seperti itu sesungguhnya merugikan gereja itu sendiri. 